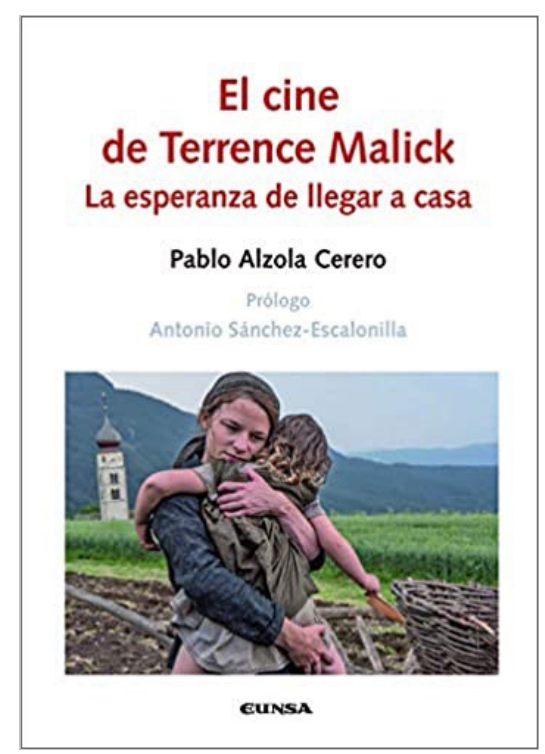

\title{
El cine de Terrence Malick. La esperanza de llegar a casa
}

\author{
Alzola Cerero, P.
}

Editorial EUNSA, Pamplona, 2020, 150 pp.

Por: Noguera Tajadura, M. ${ }^{1}$

Recibido: 8-05-2020 - Aceptado: 15-08-2020

https://doi.org/10.26441/RC19.2-2020-R3

Terrence Malick puede ser considerado como uno de los directores de cine más relevantes del panorama fílmico actual. Se trata de un cineasta singular, con un fuerte sello autoral, guionista de sus propias películas, curtido en la mayoría de los géneros, premiado en los grandes festivales y, cosa rara en los tiempos que corren, profundamente reservado en cuanto a su vida privada se refiere. Las apariciones públicas de Malick durante los estrenos y la promoción de sus filmes son prácticamente nulas: ni concede entrevistas ni acude a los pases de prensa, por lo que tiene fama de director huidizo. Quien haya querido ver en él un Salinger del cine quizá se lleve, sin embargo, una pequeña decepción, pues no parece ser una persona distante ni excéntrica. Simplemente, es un hombre tímido, según sostienen los actores que han trabajado con él, entre quienes, por cierto, se encuentran algunos de los más grandes: Martin Sheen, Michael Fassbender, Natalie Portman, Sean Penn, Cate Blanchett, Colin Farrell, Jessica Chastain o Brad Pitt.

Teniendo en cuenta que hablamos de una trayectoria profesional de unos 50 años, la filmografía de Malick hasta el día de hoy no es del todo abundante: comprende un cortometraje, nueve largometrajes de ficción y un documental, desarrollados todos ellos entre 1969 y 2019, y además de forma intermitente, pues entre el estreno de Días del cielo en 1978 y La delgada línea roja, en 1998, pasaron nada más y nada menos que veinte años en los que Malick no dirigió ninguna película. En su obra, tan alabada por unos como denostada por otros, se advierte, no obstante, una serie de líneas maestras que dan cuenta de un estilo propio y un tono narrativo y estético más o menos coherente, de aquí el interés que genera como objeto de estudio. El libro que nos ocupa, El cine de Terrence Malick. La esperanza de llegar a casa, nace precisamente de este afán por atender a la filmografía de Malick como un todo -centrándose, eso sí, en sus nueve películas de ficción-con la intención de dar con los fundamentos dramáticos y con algunos elementos de la puesta en escena que, como un hilo invisible, van entretejiendo unas cintas con otras.

El subtítulo del libro, La esperanza de llegar a casa, contiene el prisma interpretativo a través de la cual su autor, Pablo Alzola Cerero, profesor de Estética y Teoría de las Artes de la Universidad Rey Juan Carlos de Madrid, ha querido adentrarse en el cine de Malick: a partir del concepto de hogar. A lo largo de nueve capítulos se va viendo cómo el imaginario doméstico, la casa, o la acción misma de arraigarse en un lugar o habitar un espacio permea el cine de Malick en muy diferentes niveles.

\footnotetext{
${ }^{1}$ María Noguera Tajadura es Doctora en Comunicación por la Universidad de Navarra y Profesora Contratada Doctor del Departamento Cultura y Comunicación Audiovisual donde imparte Historia del Cine. mnoguera@unav. es, https://orcid.org/0000-0001-7780-6422
} 
Desde lo arquitectónico o formal, como un elemento visual que, como en los filmes de John Ford, posee su propio lenguaje y convierte los umbrales y las escaleras en símbolos en sí mismos; hasta la configuración del yo de los personajes, cuya identidad y el signo de sus relaciones personales se forjan en clave de pertenencia a un hogar; o la propia experiencia espectatorial del público, quien, en última instancia, encuentra una morada en las imágenes que se suceden en la pantalla, una más que acertada expresión que Alzola toma del teórico del cine George Toles.

La perspectiva que se adopta en esta monografía es sobre todo antropológica y filosófica. No estamos, por tanto, ante un libro de análisis fílmico. El autor, de todos modos, conoce muy bien los rudimentos de la realización y la fotografía cinematográficas, y en este sentido resulta un acierto que el mundo de las ideas nunca llegue a perder de vista el de las imágenes. A pesar de que procede de una tesis doctoral, y como bien señala Antonio Sánchez-Escalonilla en el prólogo, el texto se ha desprovisto de toda "ganga científica" y anima a disfrutar del cine no solo viéndolo sino también pensándolo. Para ello, Alzola echa mano de una gran cantidad de pensadores, la mayoría contemporáneos, entre los que destaca la figura de Stanley Cavell. También explora la huella que la Biblia ha dejado en la filmografía de Malick, no solo como fuente de inspiración narrativa sino también, en el plano visual, como una auténtica iconografía cristiana y sacramental. No podemos obviar, por otro lado, que el cine de Malick se caracteriza por su fuerte impronta filosófica, algo que, de hecho, muchos no le perdonan, pero que sin duda entronca con el talante humanístico de Alzola, quien se acerca al cine como una disciplina sin parangón para ahondar en cuestiones tan delicadas y complejas como la aceptación del sufrimiento, la experiencia de lo trascendente o el asombro ante el surgimiento de lo bello.

En definitiva, lejos de ofrecer un estudio sistemático de cada cinta, este libro profundiza en Malas tierras (1979), Días de gloria (1978), La delgada línea roja (1998), El nuevo mundo (2005), El árbol de la vida (2011), To the Wonder (2012), Knight of Cups (2015), Song to Song (2017) y Vida oculta (2019) a la luz de esa noción tan común a todos, pero a la vez tan particular de cada uno, como es la casa. Según se avanza en la lectura, se detectan los temas, los arquetipos y las imágenes que, de un modo u otro, y a través de un enfoque amplio, terminan por identificar a los protagonistas de todas estas películas como seres llamados a descubrir un hogar. Se logra, de este modo, que unos filmes iluminen el sentido de los otros, como no puede ser de otro modo en un microcosmos ficcional que posee entidad propia, y que la figura de Malick emerja finalmente como la de un cineasta preocupado por el lugar que el hombre ocupa en el mundo. 